\title{
Richness of Rhizosphere Organisms Affects Plant P Nutrition According to P Source and Mobility
}

\author{
Jean Trap ${ }^{1, *(1)}$, Patricia Mahafaka Ranoarisoa ${ }^{1}$, Usman Irshad ${ }^{2}\left(\mathbb{D}\right.$ and Claude Plassard ${ }^{1}$ \\ 1 Eco\&Sols, Institut Agro, Univ Montpellier, CIRAD, INRAe, IRD, 34060 Montpellier, France; \\ mahafaka-severine-patricia.ranoarisoa@ird.fr (P.M.R.); claude.plassard@inrae.fr (C.P.) \\ 2 Department of Environmental Sciences, COMSATS, University Islamabad, Abbottabad Campus, \\ Abbottabad 22060, Pakistan; usman_agr@yahoo.com \\ * Correspondence: jean.trap@ird.fr
}

check for updates

Citation: Trap, J.; Ranoarisoa, P.M.; Irshad, U.; Plassard, C. Richness of Rhizosphere Organisms Affects Plant P Nutrition According to P Source and Mobility. Agriculture 2021, 11, 157. https://doi.org/10.3390/ agriculture11020157

Academic Editors: Stefano Mocali and Ryusuke Hatano

Received: 5 January 2021

Accepted: 13 February 2021

Published: 16 February 2021

Publisher's Note: MDPI stays neutral with regard to jurisdictional claims in published maps and institutional affiliations.

Copyright: (c) 2021 by the authors. Licensee MDPI, Basel, Switzerland. This article is an open access article distributed under the terms and conditions of the Creative Commons Attribution (CC BY) license (https:// creativecommons.org/licenses/by/ $4.0 /)$.

\begin{abstract}
Plants evolve complex interactions with diverse soil mutualist organisms to enhance P mobilization from the soil. These strategies are particularly important when P is poorly available. It is still unclear how the soil $\mathrm{P}$ source (e.g., mineral $\mathrm{P}$ versus recalcitrant organic $\mathrm{P}$ ) and its mobility in the soil (high or low) affect soil mutualist biological (ectomycorrhizal fungi, bacteria and bacterial-feeding nematodes) richness-plant $P$ acquisition relationships. Using a set of six microcosm experiments conducted in growth chamber across contrasting $\mathrm{P}$ situations, we tested the hypothesis that the relationship between the increasing addition of soil mutualist organisms in the rhizosphere of the plant and plant $\mathrm{P}$ acquisition depends on $\mathrm{P}$ source and mobility. The highest correlation $\left(\mathrm{R}^{2}=0.70\right)$ between plant $\mathrm{P}$ acquisition with soil rhizosphere biological richness was found in a high $\mathrm{P}$-sorbing soil amended with an organic P source. In the five other situations, the relationships became significant either in soil conditions, with or without mineral P addition, or when the P source was supplied as organic $P$ in the absence of soil, although with a low correlation coefficient $\left(0.09<R^{2}<0.15\right)$. We thus encourage the systematic and careful consideration of the form and mobility of $P$ in the experimental trials that aim to assess the role of biological complexity on plant $\mathrm{P}$ nutrition.
\end{abstract}

Keywords: soil P status; rhizospheric organisms; bacteria; nematodes; mycorrhizal fungi; biodiversityfunction relationships

\section{Introduction}

Phosphorus $(\mathrm{P})$ is a fundamental nutrient for plant growth. Because plant roots only take up $\mathrm{P}$ as free orthophosphate ions, poorly concentrated in soil solution [1], P is one of the most limiting nutrients for plants worldwide [2-4]. In natural ecosystems, multiple complex ecological interactions between plants and soil organisms evolved to cope with this soil P deficiency [3]. First, roots can form a symbiosis with fungi, i.e., the mycorrhizal association, allowing them to meet their P requirements $[4,5]$. The mycorrhizal hyphae explore a large volume of soil not accessible to roots and allow translocation of $\mathrm{P}$ from the soil to the plant $[3,6,7]$. Second, roots can interact with plant growth promoting rhizobacteria (PGPR) that are able to mineralize organic P or to solubilize sorbed-P ions, increasing $\mathrm{P}$ availability for plants [8,9]. In this perspective, the bacterial strain Bacillus subtilis was often used in bio-inoculants [10]. Third, roots can interact with free-living microscopic fauna (protists and nematodes) involved in the soil microbial loop [11,12]. By grazing on bacteria and fungi, microbial feeders release high amount of orthophosphate ions, stimulate microbial activity [12], and enhancing P availability for plants [13-15]. Plants therefore have many soil partners with which they can interact to recover P from the soil. Increasing the diversity of rhizospheric interactions could be a promising way to promote plant $P$ nutrition in agro-ecology.

Importantly, these strategies have been selected over time in natural poorly-available P environment. It is thus highly probable, as pointed out by Mezeli et al. [16], that high soil 
$\mathrm{P}$ availability following mineral $\mathrm{P}$ fertilizer addition affects the flow of $\mathrm{P}$ at the soil-plant interface driven by these biological interactions. Providing massive amounts of mineral $P$ into the soil has been shown to negatively affect the functional issue of these interactions [17]. In contrast, previous studies carried out in our laboratory showed that the use of a recalcitrant source of organic $P$ such as phytate, which must be hydrolysed by specialised enzymes (phytases) before being used by plant roots, seems to benefit greatly from these interactions [14]. For example, we showed that phytate was not used by the forest tree Pinus pinaster, whether or not associated with the ectomycorrhizal basidiomycete Hebeloma cylindrosporum, demonstrating that neither the plant nor the fungal species were able to gain $P$ from phytate, indicating that these species were not able to release phytase [15]. To potentially increase phytate mineralisation, we added in the rhizophere of $P$. pinaster seedlings, ectomycorrhizal or not, the bacteria Bacillus subtilis. We chose Bacillus subtilis among diverse bacterial strains isolated from P. pinaster in the field because it was able to secrete its phytase in an external medium. Surprisingly, the sole bacterial addition did not increase the use of $\mathrm{P}$ from phytate by the plant, despite an abundant bacterial growth in the medium [13]. Remarkably, the addition of bacterial nematode grazers (Rhabditis sp.) dramatically enhanced plant $P$ accumulation from phytate [14,15]. However, until now, studies that have examined the impact of multiple inoculations in plant rhizosphere have focused on a single level of P supply, either as mineral or organic P. It is therefore essential to assess better the effect of soil $P$ source and mobility on soil biological richness-plant interactions involved in plant $\mathrm{P}$ acquisition.

In this study, our aim was to characterize how the P source and mobility affects plant $P$ nutrition based on the relationships between different rhizosphere mutualist organisms. Using our well-mastered plant-organisms consortium (P. pinaster, B subtilis and Rhabditis $s p$.) in a set of six experiments conducted in contrasting $P$ situations, we manipulated the presence of the three soil mutualist organisms (ectomycorrhizal fungi, phytase-producing bacteria, and bacterial-feeding nematodes) to create a gradient of biological richness in the rhizosphere of Pinus pinaster. We first supposed that increasing addition of mutualists does not improve plant $\mathrm{P}$ nutrition in high soil $\mathrm{P}$ availability situations. However, because ectomycorrhizal fungi, phytase-producing bacteria, and bacterial-feeding nematodes improve plant $\mathrm{P}$ acquisition through different and distinct mechanisms (soil prospection, mineralization, and excretion, respectively), we expected that the more the number of mutualists increases in plant rhizosphere, the more the plant $\mathrm{P}$ acquisition in a poor-P environment increases.

\section{Materials and Methods}

\subsection{Biological Materials}

All experiments were carried out at the Laboratory Eco\&Sols Montpellier (France) between January 2013 and December 2015. We used Pinus pinaster seedlings from Medoc (Landes-Sore-VG, France). Plant seeds were washed in water for $48 \mathrm{~h}$ at $4{ }^{\circ} \mathrm{C}$ before being sterilized in a $30 \% \mathrm{H}_{2} \mathrm{O}_{2}$ solution for $30 \mathrm{~min}$ and rinsed several times with $1 \mathrm{~L}$ of sterile deionized water, then deposited on a solid medium (agar $1.5 \mathrm{~g} \mathrm{~L}^{-1}$ and glucose $2 \mathrm{~g} \mathrm{~L}^{-1}$ ) in $90 \mathrm{~mm}$ diameter Petri dishes at $25^{\circ} \mathrm{C}$ in the dark for 2-3 weeks. For the mycorrhizal synthesis, we prepared plants in glass tubes using the ectomycorrhizal fungus Hebeloma cylindrosporum [18]. It was grown at room temperature in a standard nitrate medium [18] for three weeks in the dark using the procedure described in $[13,19]$. To prepare mycorrhizal (M) plants, we selected small pieces of solid medium with the fungal mycelium that were deposited near the roots. We produced non-mycorrhizal plants (NM) by placing germinated seedlings in the tubes without the fungus. The tubes were kept for two months in a growth chamber $\left(16 / 8 \mathrm{~h} \mathrm{light/dark}\right.$ cycle at $\left.24 / 18^{\circ} \mathrm{C}, 400 \mu \mathrm{mol} \mathrm{m}^{-2} \mathrm{~s}^{-1}, 400-700 \mathrm{~nm}, \mathrm{RH} 80 \%\right)$. We use Bacillus subtilis strain 111b. This strain is able to produce an alkaline phytase and thus use P from phytate. The bacterial strain was isolated from ectomycorrhizal roots collected in a 15-year-old P. pinaster plot in the Landes Region (France) [14]. Monoxenic populations of the bacterial-feeding nematode Rhabditis sp. were cultured on B. subtilis [15]. 


\subsection{Experimental Device and Nutrient Media}

Six experiments (A, B, C, D, E, and F) were carried out in sterile conditions using square Petri dishes $\left(12 \times 12 \mathrm{~cm}^{2}\right)$ in a climatic chamber using the experimental device [14] (Table 1).

Table 1. Protocols used in the four microcosm experiments.

\begin{tabular}{ccccccc}
\hline Experiments & A & B & C & D & E & F \\
\hline Medium & & & & & & \\
Type & Agarose & Agarose & Agarose & Soil & Soil $^{\#}$ & Soil $^{\#}$ \\
Volume & $70 \mathrm{~mL}$ & $70 \mathrm{~mL}$ & $70 \mathrm{~mL}$ & $30 \mathrm{~g}$ & $30 \mathrm{~g}$ & $30 \mathrm{~g}$ \\
Phosphorus & & & & & & \\
Source & $\mathrm{Absent}$ & $\mathrm{NaH}_{2} \mathrm{PO}_{4}$ & Phytate & Absent & $\mathrm{NaH}_{2} \mathrm{PO}_{4}$ & Phytate \\
Rate (per dish) & $/$ & $6.5 \mathrm{mg}-\mathrm{P}$ & $9.3 \mathrm{mg}-\mathrm{P}$ & $/$ & $6.5 \mathrm{mg}-\mathrm{P}$ & $9.3 \mathrm{mg}-\mathrm{P}$ \\
Duration (d) & 45 & 45 & 45 & 100 & 100 & 100 \\
Sample size & 6 & 5 & 5 & 6 & 6 & 6 \\
\hline
\end{tabular}

* All experiments used Pinus pinaster (1 individual per dish), Bacillus subtilis (10 6 per dish), Rhabditis sp. (300 individuals per dish) and Hebeloma cylindrosporum (absent or present). " Soil-bead mixture (1:1 mass ratio) with a clay soil (48\%) a $\mathrm{pH}_{\text {water }} 6.9$, total $\mathrm{N} 2.5 \mathrm{~g} \mathrm{~kg}^{-1}$, total $\mathrm{P} 0.9 \mathrm{~g} \mathrm{~kg}^{-1}$ and low bicarbonate-extractable inorganic $\mathrm{P} 3 \mathrm{mg} \mathrm{kg}^{-1}$.

Briefly, dishes were pierced with two holes, one hole in the lid for watering and the other in a corner in order to allow the growth of the plant shoot outside the dish. In experiments $\mathrm{A}, \mathrm{B}$, and $\mathrm{C}$, the nutrient medium $(70 \mathrm{~mL} /$ dish) contained $1.0 \%$ agarose (Eurobio Molecular Biology Grade), $2 \mathrm{mM} \mathrm{MgSO}_{4} 7 \mathrm{H}_{2} \mathrm{O}, 4 \mathrm{mM} \mathrm{CaSO}_{4}, 50 \mu \mathrm{g} \mathrm{L}^{-1}$ thiamine hydrochloride, $0.5 \mathrm{ml} \mathrm{L}^{-1} 1 \%$ Fe citrate, $50 \mathrm{mM}$ MOPS, $0.2 \mathrm{~mL} \mathrm{~L}^{-1}$ Morizet and Mingeau solution of micronutrients [20], $2 \mathrm{mM} \mathrm{KNO}_{3}$ and cholesterol $\left(5 \mu \mathrm{g} \mathrm{L}^{-1}\right)$. No external P was added in experiment $\mathrm{A}$. In experiment $\mathrm{B}$, the nutrient medium contained $6.5 \mathrm{mg}-\mathrm{P} / \mathrm{dish}$ as $\mathrm{NaH}_{2} \mathrm{PO}_{4}$ as the sole source of $\mathrm{P}$. In experiment $\mathrm{C}$, it contained $9.3 \mathrm{mg}-\mathrm{P} /$ dish as phytate (inositol hexakisphosphate, sodium salt, Sigma, ref P0109) as the sole source of P. We autoclaved $\left(115{ }^{\circ} \mathrm{C}, 40 \mathrm{~min}\right)$ the medium and cooled it to $55^{\circ} \mathrm{C}$ before adding filtered $(0.2 \mu \mathrm{m}$ pore size) sterilized solution of phytate and cholesterol. In experiments $\mathrm{D}, \mathrm{E}$, and F, we used the topsoil of a cambisol sampled in the south of France (Cazevieille). It is a clay soil ( $48 \%$ clay, $38 \%$ silt, $4.1 \%$ organic matter, total $\mathrm{P} 0.9 \mathrm{~g} \mathrm{~kg}^{-1}, \mathrm{pH}_{\text {water }} 6.9$, CEC $\left.21.6 \mathrm{cmol}_{\mathrm{c}} \mathrm{kg}^{-1}\right)$. This soil has a very low concentration of bicarbonate-extractable inorganic P (c.a. $3.1 \mathrm{mg} \mathrm{kg}^{-1}$ ) [21]. The soil was prepared as described by Ranoarisoa et al. [14]. Briefly, a soil-bead mixture was prepared for each replicate by mixing $15 \mathrm{~g}$ of soil, $15 \mathrm{~g}$ of glass beads, and $15 \mathrm{ml}$ of a nutrient solution containing $9.3 \mathrm{mM} \mathrm{KNO}_{3}, 9.3 \mathrm{mM} \mathrm{MgSO}_{4}$ $7 \mathrm{H}_{2} \mathrm{O}, 18.6 \mathrm{mM} \mathrm{CaSO}_{4}, 200 \mu \mathrm{g} \mathrm{L}^{-1}$ thiamine hydrochloride, $2.3 \mathrm{ml} \mathrm{L}^{-1} 1 \% \mathrm{Fe}$ citrate, and $1 \mathrm{ml} \mathrm{L}^{-1}$ solution of micronutrients in a 50-mL polypropylene tube [20]. The mixture was autoclaved twice a week at $115{ }^{\circ} \mathrm{C}$ for $40 \mathrm{~min}$. No external $\mathrm{P}$ was added in experiment D. We provided $6.5 \mathrm{mg}-\mathrm{P} /$ dish as $\mathrm{NaH}_{2} \mathrm{PO}_{4}$ as the sole source of $\mathrm{P}$ in experiment $\mathrm{E}$ and $9.3 \mathrm{mg}-\mathrm{P} /$ dish as phytate in experiment $\mathrm{F}$. Again, the solution of phytate was prepared in sterile deionized water. Before sterilization by filtration $(0.2 \mu \mathrm{m})$, the $\mathrm{pH}$ of this solution was adjusted to 7 with $\mathrm{HCl}$. After cooling, the soil-bead mixture at room temperature, each tube was opened in sterile conditions to add phytate and $350 \mu \mathrm{g}$ of cholesterol. The soil-bead mixture was homogenized by inversion overnight.

\subsection{Experimental Design}

For each experiment, six biological treatments were set up. Plants were either alone (C) or associated with different soil organisms inoculated alone or together: mycorrhiza $(\mathrm{M})$, bacteria $(\mathrm{B})$ or nematodes $(\mathrm{N})$. Nematodes were always inoculated with bacteria. We thus obtained, according to the following treatments, a gradient from 0 to 3 mutualistic organisms inoculated simultaneously with the plant: C (0), M (1), B (1), M+B (2), B+N (2), $\mathrm{M}+\mathrm{B}+\mathrm{N}$ (3). The organisms (bacteria and nematodes) were introduced at a rate of $\sim 10^{6}$ bacteria and $\sim 300$ nematodes per dish, supplied in $0.5 \mathrm{~mL}$ solution each. Five or six replicates were set up for each biological treatment according to the experiments (Table 1). 
We placed the Petri dishes horizontally in the same growth chamber and covered with aluminum foil. The plants were allowed to grow for 45 days in experiments $A, B$, and $C$ and for 100 days in the experiment D, E, and F. Each dish was humidified every week with sterile water.

\subsection{Plant and Medium Measurements}

At the beginning of each experiment, non-mycorrhizal and mycorrhizal plants were sampled to measure the initial values of plant dry weight and plant $\mathrm{P}$ content; three and six plants of each were used for experiments A-B-C and D-E-F, respectively. At the end of the experiment, the shoots and roots of each plant were separated. The root and shoot dry biomass were determined after oven-drying at $60{ }^{\circ} \mathrm{C}$ for $48 \mathrm{~h}$. The total $\mathrm{P}$ content in the shoots and roots was determined after crushing and mineralizing plant tissues with $36 \mathrm{~N} \mathrm{H}_{2} \mathrm{SO}_{4}$ acid, as described by [22]. The $\mathrm{P}$ concentration in the mineralized solution was measured using colorimetry with malachite green at $630 \mathrm{~nm}$ [23]. The plant $\mathrm{P}$ acquisition was calculated by subtracting the mean amount of total $\mathrm{P}$ contained in plants at the beginning of each experiment from individual values measured at the end of the experiment. The roots were inspected with the naked eye to check at the end of the experiment for the presence of mycorrhizae in the treatments inoculated with H. cylindrosporum. All plants from these treatments had visible ectomycorrhizae on their root systems while no mycorrhizal roots were observed for the controls. We sampled as much agar or soil-bead mixture as we possibly could without damaging the roots and used it to check for the presence of living nematodes. The occurrence of active nematodes was determined by active filtering through fine cellulose wadding paper for $48 \mathrm{~h}$ and counted using a stereoscopic microscope. We did not find nematodes in the free-nematodes treatments. There were ca 1800 nematodes per Petri dish in the experiment A (agarose with no added P), irrespective of the presence of the mycorrhizal fungi. We found ca 12,500 individuals per Petri dish in the media from the experiment B (agarose amended with mineral P) and $C$ (agarose amended with phytate) and 2000 nematodes per Petri dish in the soils from the experiment $\mathrm{D}$ (soil-bead mixture without added P), E (soil-bead mixture amended with mineral $\mathrm{P}$ ), and $\mathrm{F}$ (soil-bead mixture amended with phytate) in the " $\mathrm{B}+\mathrm{N}$ " and " $\mathrm{B}+\mathrm{N}+\mathrm{M}$ " treatments, irrespective of the presence of the mycorrhizal fungus.

\subsection{Data Analyses}

All statistical data were done with the R software [24]. In order to compare the response patterns of the different experiments, plant $\mathrm{P}$ acquisition was normalized between 0.1 and 1 using a homothetic transformation [25] with the equation: $Y=0.1+((X-b) /(a-$ b)) $\times 0.9$ where $Y$ is the value of variable after transformation; $X$ the variable to transform; a the maximum value of variable and $b$ the minimum value of variable. The untransformed data averaged per treatments are available in Table S1. Using generalized linear models $(\mathrm{glm})$ from the 'stats' package, we tested the significant interaction effect of soil mutualist biological richness $(0,1,2$, or 3$)$ and experiments (A, B, C, D, E, or F) as fixed-effects and the experiment duration (time) or sampling size ( 5 or 6 ) as random-effects. The "ranova' function from the "lmerTest" package was used to test random-effect terms. As the random effects were not significant, they were removed in the final models. The "Anova" function from the package "car" was used to compute type-III analysis of variance tables. A similar analysis was done to test the significant interaction effect of soil biological richness and the species identity (mycorrhiza, bacteria or nematode). For all models, the normality and homogeneity of variance of the residuals were tested using the Shapiro's test and Levene's tests (packages "stats" and "car"). The relationship between soil biological richness (explanatory variable) and plant $P$ acquisition (response variable) was tested for each experiment by regression using " $1 \mathrm{~m}$ " from the package "stats". Because the relationships between biological richness and functions can be expressed under different laws [26], we used a linear response as null hypothesis. The alternative hypothesis was a 
non-linear model. Thus, we used a linear model against a polynomial degree 2 to fit the data. We used the "anova" functions from the same package to compare the models.

\section{Results}

\subsection{Plant P Response to Enriched Biological Assemblages in Low-P Sorbing Medium}

We found contrasting interactive effects between soil biological richness and the experiments on plant $\mathrm{P}$ acquisition, varying from non-significant for experiments $\mathrm{A}$ and $\mathrm{B}$, slightly significant for experiments $\mathrm{C}, \mathrm{D}$, and $\mathrm{E}(p<0.05)$ to highly significant $(p<0.001)$ for experiment $\mathrm{F}$ (Table S2).

When Pinus pinaster grew in agarose without $\mathrm{P}$ supply (experiment $\mathrm{A}$ ) or supplemented with mineral $\mathrm{P}$ (experiment $\mathrm{B}$ ), increasing number in soil mutualist organisms did not cause higher plant $P$ acquisition (Figure 1). In contrast, when the agarose was supplemented with phytate (experiment $C$ ), we found a slight (slope 0.09) but significant $(p$-value $<0.05)$ higher plant $\mathrm{P}$ acquisition along the biological richness gradient (Figure 1). However, the goodness of fit was very low $\left(R^{2}=0.15\right)$; it was fairly higher for the non-additive model, but the two models were not significantly different ( $p$-value 0.147 ) (Table S2). In this P situation, we observed the highest values of plant $P$ acquisition when both bacteria and nematodes were inoculated (black triangle symbol), as shown by the significant $\mathrm{B}+\mathrm{N}$ term in Table 2.
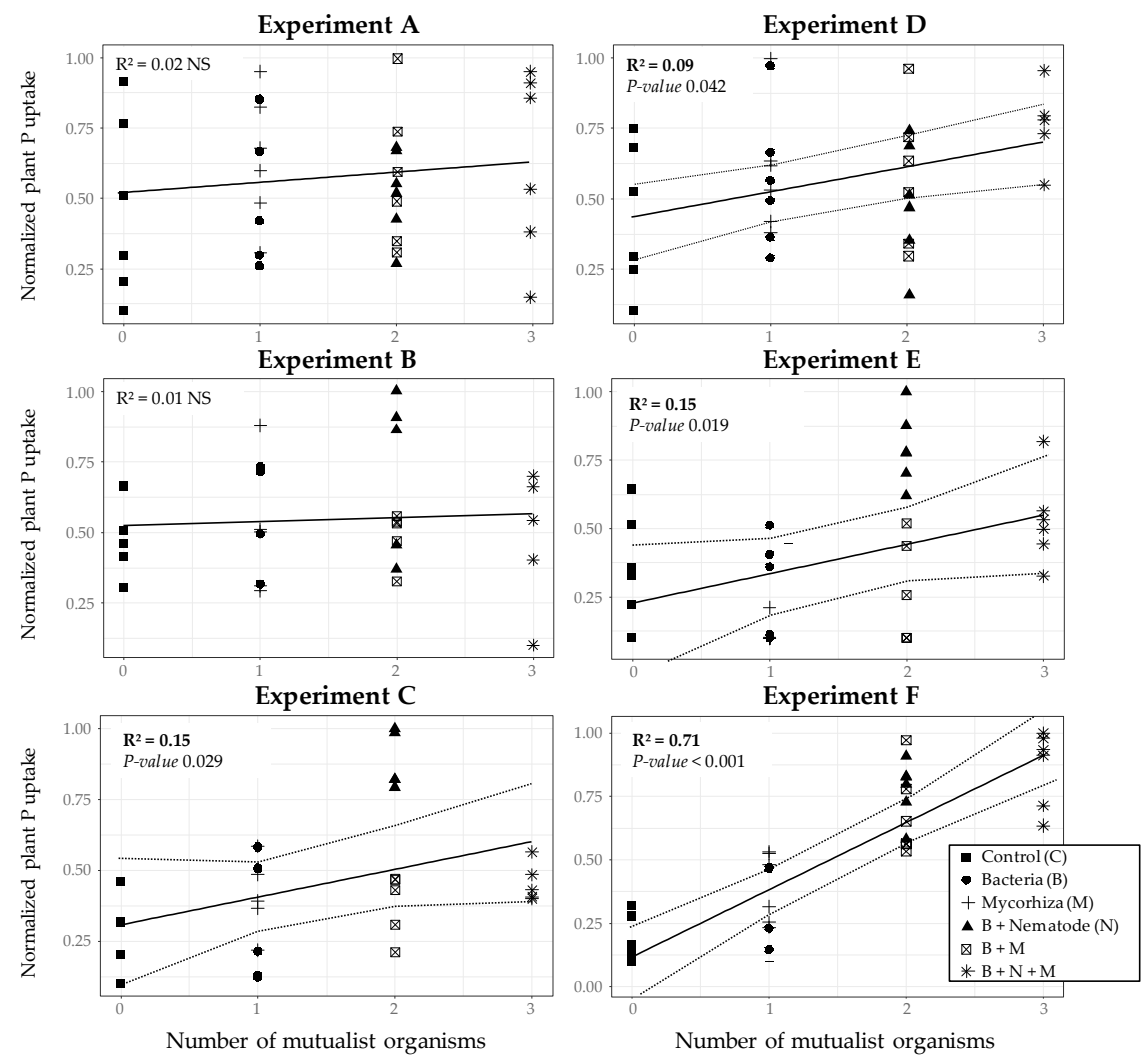

Figure 1. Linear relationships (full line) and 95\% interval confidence (dotted lines) between the number of plant mutualists inoculated in the rhizosphere of Pinus pinaster and plant $\mathrm{P}$ acquisition (normalized between 0.1 and 1) according to the experiments. The medium was agarose without $\mathrm{P}$ addition in experiment $\mathrm{A}$, supplemented with mineral $\mathrm{P}(\mathrm{Pi})$ in experiment $\mathrm{B}$ or amended with phytate in experiment $C$. We used a soil-bead mixture (soil) without $P$ addition in experiment $D$, fertilized by $\mathrm{Pi}$ in experiment $\mathrm{E}$ or amended with phytate in experiment $\mathrm{F}$. The letters " $\mathrm{C}$ ", " $\mathrm{B}$ ", " $\mathrm{M}$ ", and "N" refer to control (plant alone), bacteria (Bacillus subtilis), mycorrhiza (Hebeloma cylindrosporum), and nematode (Rhabditis sp.), respectively. NS indicates non-significant regression. 
Table 2. Coefficients of the fitting generalized linear model (glm; AIC -61.653). Significant terms $(<0.05$ threshold $)$ are in bold.

\begin{tabular}{ccccc}
\hline Terms & \multicolumn{3}{c}{ Coefficients } \\
\hline Experiment B & Estimate & Std. Error & t-Value & Pr $(>|\mathbf{t}| \mathbf{)}$ \\
Experiment C & -0.03 & 0.174 & -0.16 & 0.871 \\
Experiment D & -0.12 & 0.102 & -1.17 & 0.243 \\
Experiment E & -0.07 & 0.097 & -0.67 & 0.504 \\
Experiment F & -0.18 & 0.098 & -1.80 & 0.074 \\
Mycorhiza (M) & $-\mathbf{0 . 3 3}$ & $\mathbf{0 . 0 9 7}$ & -3.37 & $\mathbf{0 . 0 0 1}$ \\
Nematode (N) & 0.11 & 0.069 & 1.56 & 0.120 \\
Bacteria (Ba) & 0.02 & 0.084 & 0.25 & 0.807 \\
Experiment B:M & 0.01 & 0.084 & 0.13 & 0.900 \\
Experiment C:M & -0.20 & 0.110 & -1.79 & 0.076 \\
Experiment D:M & -0.18 & 0.102 & -1.80 & 0.074 \\
Experiment E:M & 0.04 & 0.097 & 0.43 & 0.669 \\
Experiment F:M & $-\mathbf{0 . 2 8}$ & $\mathbf{0 . 0 9 9}$ & $-\mathbf{2 . 8 1}$ & $\mathbf{0 . 0 0 5}$ \\
Experiment B:N & 0.12 & 0.096 & 1.23 & 0.219 \\
Experiment C:N & 0.03 & 0.147 & 0.23 & 0.816 \\
Experiment D:N & $\mathbf{0 . 3 1}$ & $\mathbf{0 . 1 2 5}$ & $\mathbf{2 . 4 5}$ & $\mathbf{0 . 0 1 5}$ \\
Experiment E:N & 0.03 & 0.119 & 0.29 & 0.776 \\
Experiment F:N & $\mathbf{0 . 3 8}$ & $\mathbf{0 . 1 2 2}$ & $\mathbf{3 . 1 3}$ & $\mathbf{0 . 0 0 2}$ \\
Experiment B:Ba & 0.31 & $\mathbf{0 . 1 1 7}$ & $\mathbf{2 . 6 8}$ & $\mathbf{0 . 0 0 8}$ \\
Experiment C:Ba & -0.01 & 0.120 & 0.75 & 0.452 \\
Experiment D:Ba & 0.05 & 0.125 & -0.09 & 0.930 \\
Experiment E:Ba & 0.01 & 0.119 & 0.39 & 0.699 \\
Experiment F:Ba & 0.14 & 0.119 & 0.07 & 0.945 \\
\hline
\end{tabular}

\subsection{Plant P Response to Enriched Biological Assemblages in High-P Sorbing Medium}

When we used the soil-bead mixture without $P$ addition (experiment $D$ ), the increasing addition of organisms caused a very slight increase in plant $P$ uptake $\left(R^{2}=0.09\right)$. In the experiment $\mathrm{E}$, in soil-bead mixture supplemented with orthophosphate ions, the inoculation of an increasing number of mutualist organisms affected $p$. pinaster $\mathrm{P}$ acquisition in a similar way as experiments $C$ and $D$ (linear model, slope $0.10, R^{2}=0.15, p$-value $<0.05$ ). Again, we observed the highest values when both bacteria and nematodes were inoculated (Figure 1). The presence of nematode and also mycorrhiza induced a significant increase in plant $P$ uptake (Table 2). In the last case (experiment F), when phytate was supplied in the soil-bead mixture, plant $P$ acquisition was strongly significantly related to biological richness (slope $0.26, R^{2}=0.71, p$-value $\left.<0.001\right)$. The additive linear model was selected as the best model since the polynomial degree 2 did not significantly differ from the linear model ( $p$-value 0.822) (Table S2).

\section{Discussion}

Using a set of six experiments conducted in contrasting P availability situations, we aimed at testing how the $\mathrm{P}$ form and mobility in the root environment affects the effects of enriched biological assemblages on plant $\mathrm{P}$ nutrition. In experiment $\mathrm{A}$, the $\mathrm{P}$ amount was extremely low, as it came from agarose (representing around $30 \mu \mathrm{g} P /$ dish) and from inoculated bacteria $\left(10^{6}\right.$ bacteria, representing $330 \mu \mathrm{g}$ of total $\left.\mathrm{P}\right)$. These experimental conditions can explain why adding organisms had no effect on plant $P$ uptake during the experiment. They suggest also that the grazing of bacteria by nematodes was not able to provide $\mathrm{P}$ to the plants. In experiment $\mathrm{B}$, the introduced orthophosphate ions were highly mobile. Consequently, plant roots can directly take up $\mathrm{P}$ without the help of soil organisms, explaining the absence of a significant pattern between biological richness and plant $\mathrm{P}$ uptake in this medium. In experiment $\mathrm{C}$, phytate was also mobile in the medium but the pattern between plant $P$ acquisition and the number of mutualists is still low. This situation was mostly caused by the inefficient role of the mycorrhizal fungus 
in agarose ( $p$-value 0.074, Table 2). This fungal species is unable to produce phytases [27] and to mobilize $P$ from phytate [15]. Consequently, the inoculation of $H$. cylindrosporum in the experiment $C$ did not help the plant to mobilize $P$ from the medium, irrespective of the presence of bacteria or nematodes. We observed a slight decrease in the amount of $\mathrm{P}$ taken by pine following fungus inoculation (Figure 1). We believe that this slight decrease could come from the short duration of our experience (45 days), which favored the immobilization of $\mathrm{P}$ in the biomass of the young growing fungus. We also noticed that the initial content of $\mathrm{P}$ in the two-month old mycorrhizal plants was $27 \%$ greater than the non-mycorrhizal plants after the mycorrhizal synthesis in glass tubes, while plant weights were similar. Therefore, a higher $\mathrm{P}$ amount of $\mathrm{P}$ was subtracted from the final values when the plants were mycorrhized. In contrast to mycorrhiza, the addition of nematodes was significant in this experiment $C$ ( $p$-value 0.015 , Table 2 ). By releasing immobilized $P$ from the microbial biomass, bacterial-feeding nematodes could provide available $P$ to the roots via the soil microbial loop $[11,20]$. Alternatively, bacterial grazing could enhance the release of bacterial phytase compared to bacteria inoculated alone, increasing the hydrolysis of phytate and Pi availability to the plant, whether or not associated with the fungus.

In the soil-bead mixture without $P$ addition, $P$ availability was very low as indicated by bicarbonate-extractable P concentrations around $3 \mathrm{mg} \cdot \mathrm{kg}^{-1}$ of dry soil. Nevertheless, plant $P$ uptake increased slightly with the number of mutualists associated with the plant. Taken individually, none of the treatment was able to increase plant $\mathrm{P}$ acquisition, even the mycorrhizal fungus (Table 2). In similar conditions of growth, the efficiency of the same mycorrhizal association on plant $\mathrm{P}$ acquisition depended strictly on the area of soil covered by $H$. cylindrosporum hyphae and on the duration of experiment that must be greater than four months to allow a sufficient development of the fungus on the soil and the net transfer of $P$ to the plant [22]. Hence, the short duration of experiment D could explain the lack of effect of mycorrhizal association.

When the soil-bead mixture was fertilized by mineral P (experiment E), most of the provided mineral $\mathrm{P}$ was probably sorbed on the soil constituents [28], but a large amount would be available for the roots. Here, we observed a significant negative effect of the fungus on plant $P$ uptake ( $p$-value 0.005 , Table 2 ). Such a negative effect was observed by Aquino and Plassard [22] with the same association grown in similar conditions. These authors suggested that the $\mathrm{P}$ uptake of mycorrhizal plants could depend only on the fungal pathway needing more than four months of growth to be able to provide more $\mathrm{P}$ than the direct pathway occurring through the roots. Hence, as in experiment D, these results could be explained by the short duration of the experiment (three months). In contrast, as quoted earlier, the role of bacterial-feeding nematodes was central ( $p$-value 0.002, Table 2). This positive effect of nematodes to increase plant $P$ availability must have occurred via the microbial loop. Lastly, when the soil-bead mixture was amended with phytate in experiment $\mathrm{F}$, the inoculation of an increasing number of mutualistic organisms caused an increasing plant $\mathrm{P}$ acquisition, validating the null linear hypothesis. Remarkably, the development of the fungus was very strong in the soil-bead mixture (see Figure S1) and could have contributed strongly to plant $P$ uptake from mineralized phytate by the bacterial phytase.

The key role of nematode in experiments $\mathrm{C}, \mathrm{E}$, and F seems to indicate selection (i.e., the effects due to the presence of a particular species with high (or low) dominant impact in an assemblage) rather than complementarity effects (i.e., the effects caused by synergism or antagonism) $[29,30]$. In contrast, in this experiment $F$, the linear relationship was mostly explained by both mycorrhiza and nematodes, suggesting that additive effects between mycorrhiza and nematodes (and their associated bacterial prey) may have occurred. We did not compute net diversity effects because it was not possible to measure the performance of each species within assemblage on plant $P$ acquisition. 


\section{Conclusions}

We showed that the effect of increasing the addition of mutualist organisms in the rhizosphere of the plant improves plant $\mathrm{P}$ nutrition only in particular $\mathrm{P}$ situations. More precisely, the input of organic $\mathrm{P}$ source in a high P-sorbing soil promoted positive relationships between biological richness and plant $\mathrm{P}$ nutrition. The chemical nature (mineral versus organic) of the $\mathrm{P}$ source and the mobility of $\mathrm{P}$ in the soil shape the functional issues of the complex relationships between soil biological diversity and plant roots. Our findings highlight the importance to consider carefully the form and mobility of P in experimental studies that aim at assessing the role of biological complexity on plant $\mathrm{P}$ nutrition.

Supplementary Materials: The following are available online at https:/ /www.mdpi.com/2077-0 $472 / 11 / 2 / 157 /$ s1. Table S1. Raw data of plant P amount in mg-P per Petri dish for each replicate according to treatments. Table S2. Fitting parameters $\left(\mathrm{R}^{2}, p\right.$-value) for each experiment with linear (additive hypothesis) or polynomial (non-additive hypothesis) models. Figure S1. Photography of the root system from an ectomycorrhizal plant extracted from the Petri dish at the end of the experiment (experiment F). The very important development of the mycorrhizal fungus H. cylindrosporum in the soil-bead mixture leads to a strong aggregation of the soil around the roots of pine.

Author Contributions: Conceptualization, J.T. and C.P.; methodology, J.T. and C.P.; data acquisition, J.T., U.I., P.M.R., and C.P.; formal analysis, J.T. and C.P.; writing-original draft preparation, J.T.; writing - review and editing, all authors; project administration, C.P.; funding acquisition, C.P. All authors have read and agreed to the published version of the manuscript.

Funding: This research was funded by the ANR project "UNLOCKP" (ANR 11 BSV7 015 01, France) awarded to C.P. This work was also supported by the program 'Investments of the future' (ANR-10LABX-04-01) by the use of the Ecotrop platform from CeMEB labEx.

Institutional Review Board Statement: Not applicable.

Informed Consent Statement: Not applicable.

Data Availability Statement: The data presented in this study are available on request from the corresponding author.

Acknowledgments: We are grateful to Pierre Trichet (ISPA, INRAe Bordeaux) for providing us with the soil samples for nematode isolation. We thank P. Deleporte for his help in data analyses. We thank Valentin Lauret, Guillaume Pugliese, Sebastian Mira, and Olivier Pacholick for their help during the experiments.

Conflicts of Interest: The authors declare no conflict of interest.

\section{References}

1. Hinsinger, P. Bioavailability of soil inorganic $P$ in the rhizosphere as affected by root-induced chemical changes: A review. Plant Soil 2001, 237, 173-195. [CrossRef]

2. Du, E.; Terrer, C.; Pellegrini, A.F; Ahlström, A.; van Lissa, C.J.; Zhao, X.; Xia, N.; Wu, X.; Jackson, R.B. Global patterns of terrestrial nitrogen and phosphorus limitation. Nat. Geosci. 2020, 13, 221-226. [CrossRef]

3. Becquer, A.; Trap, J.; Irshad, U.; Ali, M.A.; Claude, P. From soil to plant, the journey of P through trophic relationships and ectomycorrhizal association. Front. Plant Sci. 2014, 5, 548. [CrossRef] [PubMed]

4. Plassard, C.; Dell, B. Phosphorus nutrition of mycorrhizal trees. Tree Physiol. 2010, 30, 1129-1139. [CrossRef]

5. Smith, S.E.; Jakobsen, I.; Grønlund, M.; Smith, F.A. Roles of arbuscular mycorrhizas in plant phosphorus nutrition: Interactions between pathways of phosphorus uptake in arbuscular mycorrhizal roots have important implications for understanding and manipulating plant phosphorus acquisition. Plant Physiol. 2011, 156, 1050-1057. [CrossRef]

6. Plassard, C.; Louche, J.; Ali, M.A.; Duchemin, M.; Legname, E.; Cloutier-Hurteau, B. Diversity in phosphorus mobilisation and uptake in ectomycorrhizal fungi. Ann. For. Sci. 2011, 68, 33-43. [CrossRef]

7. Smith, S.E.; Smith, F.A. Roles of arbuscular mycorrhizas in plant nutrition and growth: New paradigms from cellular to ecosystem scales. Annu. Rev. Plant Biol. 2011, 62, 227-250. [CrossRef] [PubMed]

8. Khan, A.A.; Jilani, G.; Akhtar, M.S.; Naqvi, S.M.S.; Rasheed, M. Phosphorus solubilizing bacteria: Occurrence, mechanisms and their role in crop production. J. Agric. Biol. Sci. 2009, 1, 48-58.

9. Gyaneshwar, P.; Kumar, G.N.; Parekh, L.J.; Poole, P.S. Role of soil microorganisms in improving P nutrition of plants. Plant Soil 2002, 245, 83-93. [CrossRef] 
10. Herrmann, L.; Lesueur, D. Challenges of formulation and quality of biofertilizers for successful inoculation. Appl. Microbiol. Biotechnol. 2013, 97, 8859-8873. [CrossRef]

11. Clarholm, M. Interactions of bacteria, protozoa and plants leading to mineralization of soil-nitrogen. Soil Biol. Biochem. 1985, 17, 181-187. [CrossRef]

12. Trap, J.; Bonkowski, M.; Plassard, C.; Villenave, C.; Blanchart, E. Ecological importance of soil bacterivores for ecosystem functions Plant Soil 2016, 398, 1-24. [CrossRef]

13. Irshad, U.; Villenave, C.; Brauman, A.; Plassard, C. Grazing by nematodes on rhizosphere bacteria enhances nitrate and phosphorus availability to Pinus pinaster seedlings. Soil Biol. Biochem. 2011, 43, 2121-2126. [CrossRef]

14. Ranoarisoa, M.P.; Trap, J.; Pablo, A.L.; Dezette, D.; Plassard, C. Micro-food web interactions involving bacteria, nematodes, and mycorrhiza enhance tree P nutrition in a high P-sorbing soil amended with phytate. Soil Biol. Biochem. 2020, 143, 107728. [CrossRef]

15. Irshad, U.; Brauman, A.; Villenave, C.; Plassard, C. Phosphorus acquisition from phytate depends on efficient bacterial grazing, irrespective of the mycorrhizal status of Pinus pinaster. Plant Soil 2012, 358, 148-161. [CrossRef]

16. Mezeli, M.M.; Page, S.; George, T.S.; Neilson, R.; Mead, A.; Blackwell, M.S.; Haygarth, P.M. Using a meta-analysis approach to understand complexity in soil biodiversity and phosphorus acquisition in plants. Soil Biol. Biochem. 2020, 142, 107695. [CrossRef]

17. Johnson, N.C. Can fertilization of soil select less mutualistic mycorrhizae? Bull. Ecol. Soc. Am. 1993, 3, 749-757. [CrossRef]

18. Marmeisse, R.; Guidot, A.; Gay, G.; Lambilliotte, R.; Sentenac, H.; Combier, J.P.; Melayah, D.; Fraissinet-Tachet, L.; Debaud, J.C. Hebeloma cylindrosporum-a model species to study ectomycorrhizal symbiosis from gene to ecosystem. New Phytol. 2004, 163, 481-498. [CrossRef]

19. Becquer, A.; Torres-Aquino, M.; Le Guernevé, C.; Amenc, L.K.; Trives-Segura, C.; Staunton, S.; Quiquampoix, H.; Plassard, C. Establishing a symbiotic interface between cultured ectomycorrhizal fungi and plants to follow fungal phosphate metabolism. Bio-Protocol 2017, 7, e2577. [CrossRef]

20. Morizet, J.; Mingeau, M. Influence des facteurs de milieu sur l'absorption hydrique. Etude effectuee sur tomate decapitee en exsudation. i. facteurs nutritionnels. Ann. Agron. 1976, 27, 183-205.

21. Casarin, V.; Plassard, C.; Souche, G.; Arvieu, J.C. Quantification of oxalate ions and protons released by ectomycorrhizal fungi in rhizosphere soil. Agronomie 2003, 23, 461-469. [CrossRef]

22. Aquino, M.; Plassard, C. Dynamics of ectomycorrhizal mycelial growth and P transfer to the host plant in response to low and high soil P availability. FEMS Microbiol. Ecol. 2004, 48, 149-156. [CrossRef] [PubMed]

23. Ohno, T.; Zibilske, L.M. Determination of low concentration of phosphorus in soil extracts using malachite green. Soil Sci. Soc. Am. J. 1991, 55, 892-895. [CrossRef]

24. Team, R.C. RStudio: Integrated Development for R. 2016. Available online: https://rstudio.com/products/rstudio (accessed on 20 November 2015).

25. Velásquez, E.; Lavelle, P.; Andrade, M. GISQ, a multifunctional indicator of soil quality. Soil Biol. Biochem. 2007, 39, 3066-3080. [CrossRef]

26. Naeem, S.; Loreau, M.; Inchausti, P. Biodiversity and ecosytsem functioning: The emergence of a synthetic ecological framework. In Biodiversity and Ecosystem Functioning: Synthesis and Perspectives; Loreau, S.M., Naeem, P., Eds.; Inchausti. Oxford University Press: Oxford, UK, 2002.

27. Louche, J.; Ali, M.A.; Cloutier-Hurteau, B.; Sauvage, F.X.; Quiquampoix, H.; Plassard, C. Efficiency of acid phosphatases secreted from the ectomycorrhizal fungus Hebeloma cylindrosporum to hydrolyse organic phosphorus in podzols. FEMS Microbiol. Ecol. 2010, 73, 323-335. [CrossRef]

28. Devau, N.; Le Cadre, E.; Hinsinger, P.; Jaillard, B.; Gérard, F. Soil pH controls the environmental availability of phosphorus: Experimental and mechanistic modelling approaches. Appl. Geochem. 2009, 24, 2163-2174. [CrossRef]

29. Loreau, M.; Hector, A. Partitioning selection and complementarity in biodiversity experiments. Nature 2001, 412, 72-76. [CrossRef] [PubMed]

30. Loreau, M.; Naeem, S.; Inchausti, P.; Bengtsson, J.; Grime, J.P.; Hector, A.; Hooper, D.U.; Raffaelli, D.; Schmid, B.; Tilman, D.; et al. Biodiversity and Ecosystem Functioning: Current Knowledge and Future Challenges. Science 2001, 294, 804-808. [CrossRef] [PubMed] 